\title{
Putting faces to global pandemics
}

Pandemic Influenza Storybook:

Personal recollections from survivors, families and friends

Sharon K.D. Hoskins, Coordinator/editor United States Centers for Disease Control and Prevention; 2008

www.pandemicflu.gov/storybook/index.html

$\mathrm{W}$

hat would happen if the public saw and heard firsthand accounts from individuals and their families who were affected by an influenza pandemic? Would the prevention message stick? Would it pre-empt a repeat of the Torontonians who, despite being under quarantine during the 2003 SARS outbreak, chose to nip out to the drugstore or visit friends? Would it result in less fear, better understanding and fewer deaths?

The first-ever online storybook of real people telling real stories is a foray in this direction, with compelling narratives that bring to life the public health reality - albeit one from decades ago.

Launched online in August 2008 by the United States Centers for Disease Control and Prevention, the Pandemic Influenza Storybook portrays the frightening 1918 pandemic in the words of survivors, family members and others who recall the fear and hysteria, packed hospitals, empty schoolhouses and silent streets. Their stories resonate in a way no governmentissued statement ever could. They remind us of how quickly a virus can move and the haunting legacy it often leaves in its wake: grandchildren who never know grandparents. Siblings separated when 1 or both parents die. An entire family of 8 buried side by side. Doctors and other health care workers dying on duty. It also tells how epidemics can inspire survivors to become doctors, researchers and epidemiologists.

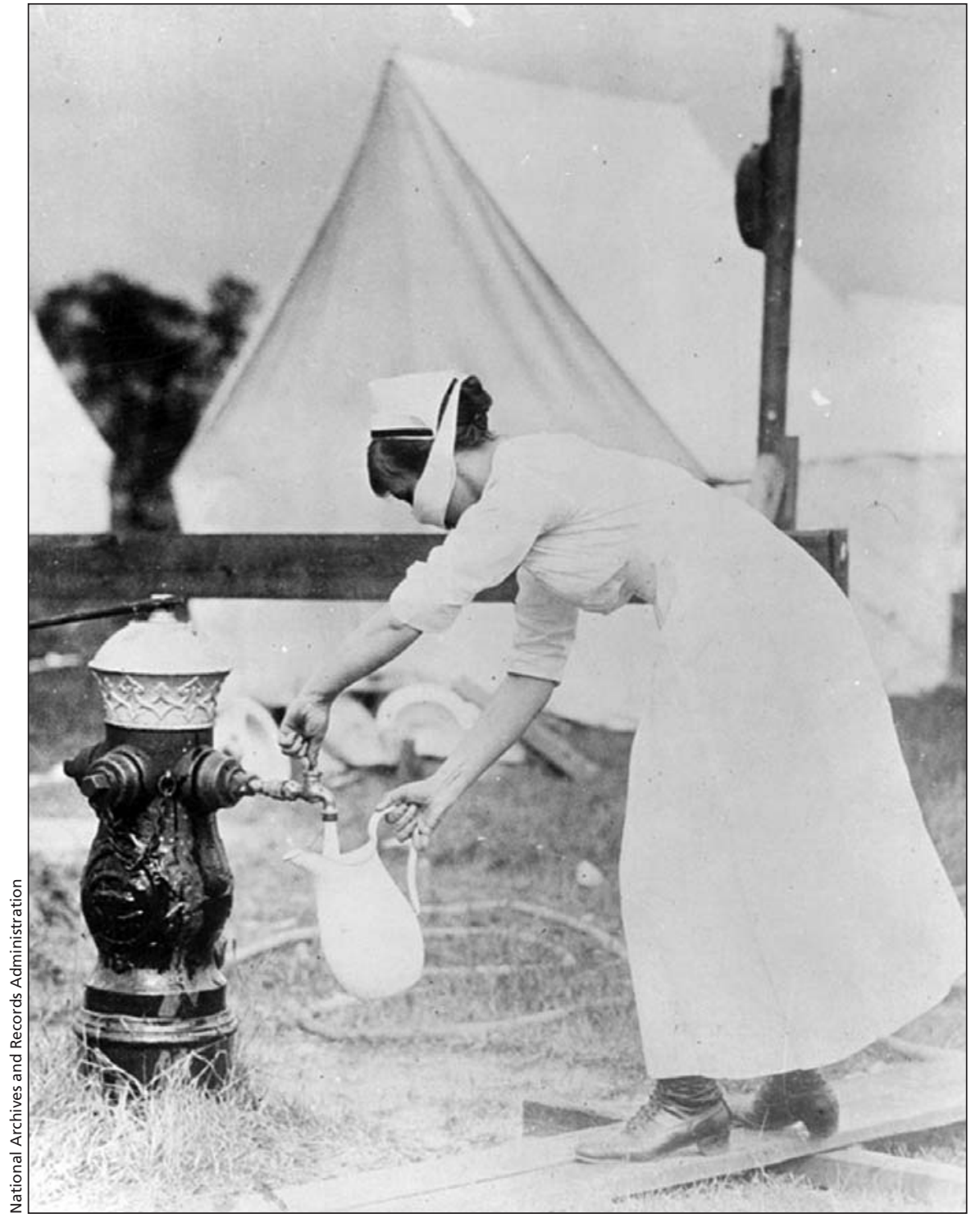

Nurses and doctors attempted to protect themselves from the 1918 influenza.

Historical photos, newspaper articles and public health posters of the times also recall the tone and reality of the pandemic, as do tales of elixirs, such as herbs, goat's milk and moonshine.

The idea for the storybook emerged during recent crisis and emergency risk training, particularly during the avian flu panic when health agencies were di- rected to get prepared for the worsecase scenario. The storybook is aimed in part at these public health professionals in the hope that putting some of the faces and names on a global pandemic that killed 50 million people worldwide will help fight "preparedness fatigue."

The storybook may also help the 
general public to better understand the reality of a pandemic and the importance of the precautions and plans put in place at local health districts for mass emergencies, such as influenza and bioterrorism.

In the storybook, Debbie Crane of North Carolina recounts a harrowing, but all too common, tale. She initially learned about her family's flu fatalities when she saw that numerous relatives had the same year of death on their tombstones. Her grandmother, Edna Breedlove Clampitt then told her about the time her family (5 siblings, pregnant mother and father) lived in a cabin in Swain County, North Carolina, "disconnected from the rest of the world" where no one had heard about the flu:

"One of my grandmother's brothers, Wade Breedlove, had joined the army. The family was thrilled when he came home for a visit in November. They 'put the big pot in the little pot' for his visit, which means that they cooked special meals and everyone came to visit. No one knew that their brother had brought an untimely death as well. He became ill shortly after he returned to base, but survived. The rest of the family wasn't so lucky. By midDecember, the whole family was terribly ill. They ached. Their throats hurt.
They coughed and coughed. My greatgrandmother, Ida Mae Breedlove, gave birth even as she lay sick. My grandmother described one terrible night when the whole family sounded as if they were all drowning. In the morning, Ida and 2-year-old Woodrow were dead. The newborn, Paul, died days later. My grandmother was never sure if it was the flu that killed him, or if he simply starved to death in a household where everyone was just too weak to take care of him."

It was public health troops out in the field who first heard such tales and relayed them to colleagues during Crisis \& Emergency Risk Communication training, which began in 2002. US Centers for Disease Control and Prevention trainers used these stories as part of the course and trainees asked the Center to compile some of the stories and make them available to the public. Since 2008 is also the 90th anniversary of the 1918 pandemic influenza, the Center decided to create a commemorative online package.

Requests for stories about the 1918 pandemic, as well as those in 1957 and 1968 made the rounds on listservs in January 2008. Within 3 hours the first new story arrived. The Centers for Disease Control and Prevention will continue to

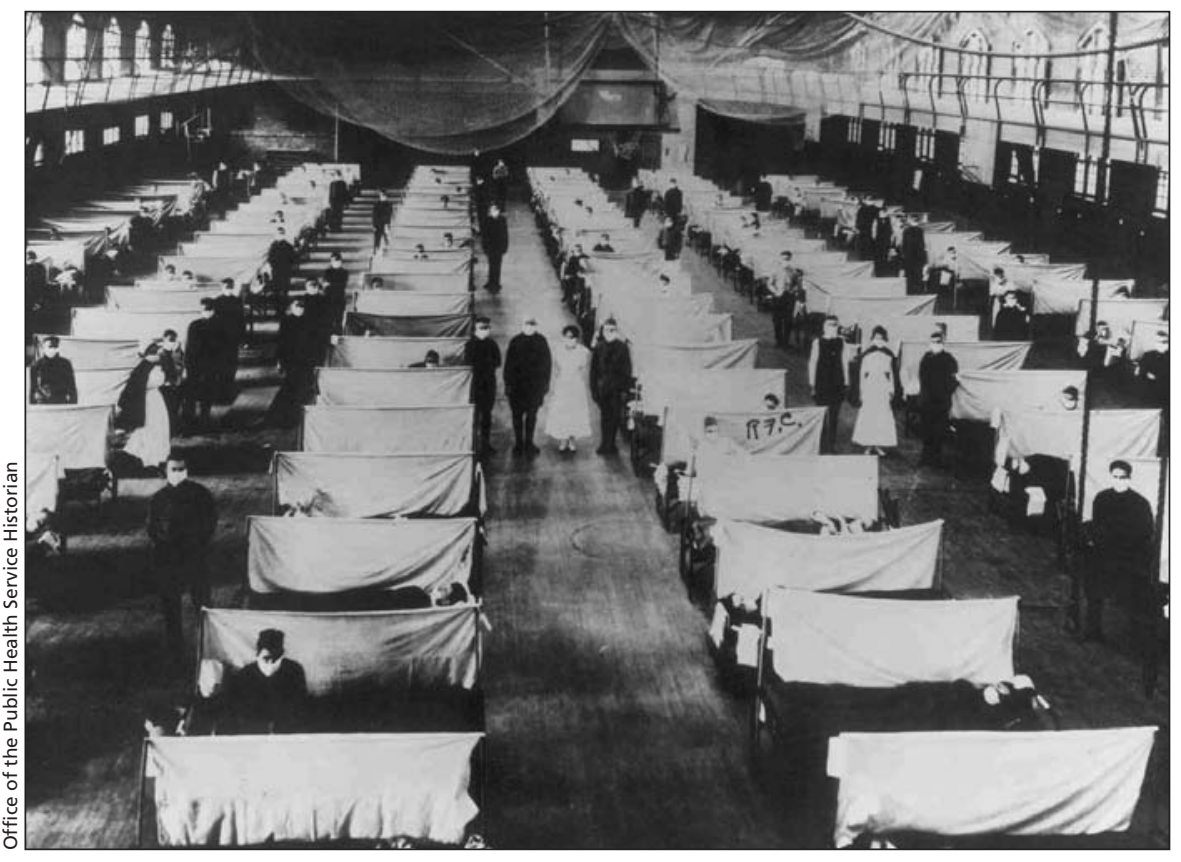

When it came to treating influenza patients in the United States in 1918, health care professionals, including doctors, nurses and druggists, were at a loss.

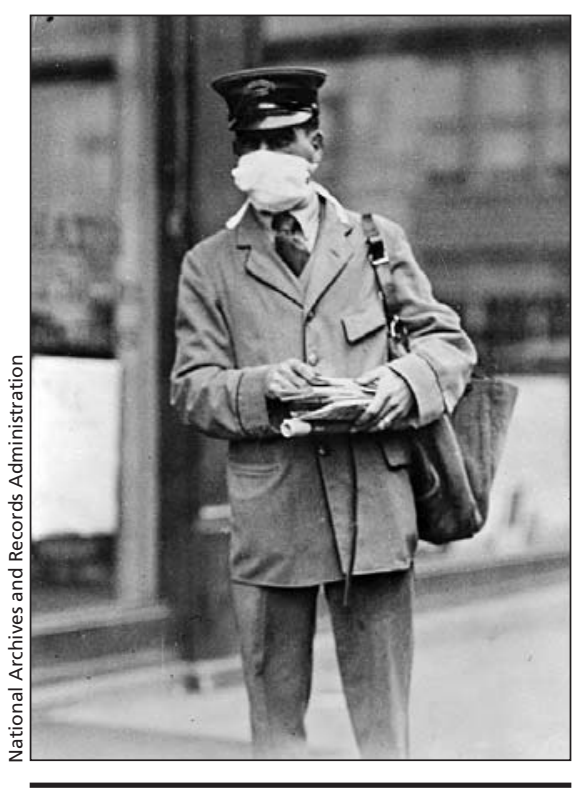

During the 1918 influenza pandemic service workers who frequently came into contact with the public often wore masks in an attempt to ward off the disease. These masks, however, were ineffective in preventing the spread of influenza.

accept stories and add them to the book at quarterly intervals.

The reason for the 1918 pandemic's astounding deadly toll, of course, is that no antibiotics existed to treat the bacterial pneumonia that influenza commonly triggers. Most victims succumbed to bacterial pneumonia following influenza virus infection, the US National Institute of Allergy and Infectious Diseases concluded in a recently released report. When subsequent flu epidemics erupted in 1957 and 1967, far fewer people died. The 90-year-old pandemic made headlines again in August 2008 when scientists revealed that survivors, now aged 91 to 101 , carry a memory of that virus in their immune systems and can produce antibodies to kill it. ${ }^{1}$

Now, that's a virus with a story to tell.

\section{Patricia S. Guthrie MA}

Freelance health writer Seattle, Wash.

\section{REFERENCE}

1. Yu X, Tsibane T, McGraw PA, et al. Neutralizing antibodies derived from the B cells of 1918 influenza pandemic survivors. Nature 2008;455:532-6. 